\section{State of Illinois Credit and Investment Analysis}

\author{
David Raymond $^{1} \&$ Ryan Olson ${ }^{2}$ \\ 12david.raymond@gmail.com \\ 2ryan.olson42@outlook.com
}

\section{INTRODUCTION}

The State of Illinois has the potential to be a powerful force in the United States economy. According to 2016 data released by the Airports Council International-North America, Illinois has two airports - O'Hare International and Midway - ranked 6th and 90th worldwide, and 3rd and 26th nationally for total passengers; O'Hare also ranks 6th nationally and 20th worldwide for annual cargo transported, with Chicago-Rockford International Airport also ranking 35th nationally and 136th worldwide (Airports Council International-North America [ACINA]). Illinois is also the only state where all seven Class I railroads operate - the coast-to-coast freight trains has the second-largest rail network in the nation with 7,000 miles of track (Texas being first) and contains the City of Chicago, which is the nation's busiest rail freight hub and the third largest container port in the world behind Singapore and Hong Kong (American-Rails.com 2018; Illinois Department of Transportation 2016). With infrastructure ranking this highly, both nationally and internationally, it would be reasonable to assume that Illinois is a prime location for businesses; however, Illinois is currently consumed by financial instability resulting from a high level of pension system debt that accounts for roughly $25 \%$ of the General Fund budget (Commission on Government Forecasting \& Accountability [CGFA] 2017). Illinois may serve as a benchmark in the nation for transportation and shipping, but it also serves as the quintessential example of fiscal mismanagement among states.

As of December 2, 2018, Illinois' general obligation bonds have a credit rating of Baa3 with a Stable Outlook from Moody's; BBB- with a Stable Outlook from Standard \& Poor's; and BBB with a Negative Outlook from Fitch Ratings (State of Illinois Comptroller 2018). For Moody's and
Standard \& Poor's, their ratings are one step above "junk" ratings; though no state in the United States has ever received a junk rating (Pierog 2017). If current trends continue, Illinois faces the prospect of crossing into uncharted territory unless it rectifies two problems: consistent financial mismanagement, and increasing unfunded pension liabilities.

The following credit and investment analysis of Illinois begins with the history of Illinois' mismanagement of the pension system from 1989 to 2018. Then, the analysis compares debt ratios from Fiscal Year 2010 and Fiscal Year 2018, before comparing economic and demographic indicators between Illinois and the surrounding states in the Midwest. Next, two bonds will be analyzed to reflect on the price history until its maturity; first is a general obligation taxable bond used to fund part of the pension system, second is a general obligation tax-exempt bond used to terminate Illinois' only outstanding variable rate general obligation bond. Last, we propose three solutions to Illinois' pension and debt crisis to fix the prevailing causes based on our research and analyses.

\section{HISTORY \\ 1989-2000}

The history of financial mismanagement and the rapid growth of unfunded pension liabilities starts in 1989. Governor James Thompson (R) changed the cost-of-living adjustment factor in the pension funding formula from an annual fixed three percent to an annual compounding three percent. This move alone added $\$ 1.3$ billion to Illinois' unfunded pension liabilities (McKinney 2015). Five years later in 1994, Governor Jim Edgar (R) implemented a plan that has become labeled the 'Edgar Ramp'.

The Edgar Ramp outlined Governor Edgar's plan to fund the pension system at 90 percent funded by 2045 (McKinney 2015). For the first fifteen years, payments into the pension system would be artificially low, then significantly increased in the following years. When the Edgar Ramp took effect in 1996, the initial projection was for the pension system to be $52 \%$ funded until 1999, when the funded ratio would decrease to 51\% until Fiscal Year 2004, when it would continually increase until 
reaching 90\% in 2045 (CGFA 2006). The actual funded ratio of the pension system would prove to be radically different from the 1994 projections. A graphical representation of the Edgar Ramp's original funding projections and how Illinois actually funded the pension system can be seen in Figure 1 within the Appendix.

From 1996 to 2002, the actual funded ratio was significantly above the Edgar Ramp's predictions. Whereas the projections stated a $52 \%$ ratio from 1996 to 1998, then 51\% from 1999 to 2002, Illinois actually funded the pension system between $70 \%$ to $74 \%$ from 1997 to 2000 . After 2000, the funded ratio continued to decrease until 2003, when it bottomed out at $48.6 \%-3.1 \%$ below the Edgar Ramp's projected funded ratio (CGFA 2006). According to Illinois' Commission on Government Forecasting and Accountability, the driving factor behind the substantial decrease in the funded ratio was very poor investment returns in Fiscal Year 2001 and 2002 combined with the failure of the state government to make sufficient employer contributions (CGFA 2006, p. 7). In Fiscal Year 2003, the funded ratio returned to above Edgar Ramp projections (60.9\% vs. $52.1 \%$ ) and stayed above until 2008, when the funded ratio dropped from $62.6 \%$ in 2007 to $38.3 \%$ in 2010 (CGFA 2013, p. 28). This decrease in the funded ratio was caused by large investment losses from the Great Recession which increased the unfunded liabilities by $\$ 12.2$ billion between 2007 and 2008, and \$23.4 billion from 2008 to 2009 (CGFA 2013, p. 26). Since the Great Recession ended, the funded ratio for the pension systems has not recovered and has fluctuated between a high of $43.3 \%$ in 2011 and a low of $37.6 \%$ in 2016 (CGFA 2018, p. 35). As of 2018, the unfunded liabilities total $\$ 129.1$ billion with a funded ratio of $39.8 \%$.

Since the Edgar Ramp was first implemented in 1996, the pension system's unfunded liabilities have increased by $\$ 110.1$ billion (CGFA 2018, p. 34). Despite the losses on investments during the Great Recession and the early 2000s recession playing a significant role in decreasing the funded ratio, investment gains in excess of expectations in Fiscal Years 2013, 2014, and 2017 offset part of those losses. As of 2018, investment returns only account for a cumulative unfunded liability increase of $\$ 14.052$ billion since 1996 (CGFA 2018). The most significant factor has been insufficient contributions by the state government that have increased unfunded liabilities by $\$ 47.859$ billion. Other factors are (i) changes in assumptions (rate of return on investments, rates of salary increases, mortality, retirement, etc.) caused the state to make inadequate contributions and increased the unfunded liability by $\$ 31.005$ billion; (ii) changes in assumptions about state demographics increased unfunded liabilities by $\$ 16.151$ billion; and (iii) increases in benefits which added $\$ 5.804$ billion. The only factor that reduced unfunded liabilities was salary increases being lower than the estimates (CGFA 2018).

\section{0-2018}

Fiscal mismanagement extended into the millennium when Governor George Ryan (R) opted to avoid laying off nearly 7,000 state workers including downstate and suburban teachers - by presenting pension beneficiaries the option to speed up their retirements by purchasing "age and service credits needed to qualify for a pension" (McKinney 2015, Exit Strategy section, para. 2). According to McKinney (2015), Governor Ryan "signed off on an early-retirement program for state workers and suburban and downstate teachers that increased the liability to the state pension systems by $\$ 2.3$ billion" (Exit Strategy section, para. 5). The Report on the Cost and Savings of the State Employees' Early Retirement Incentive (ERI) Program (2006) accounts that Ryan's legislation, entitled Public Act 93-0839, "required the ERI to be calculated, based on the increase in the present value of future benefits resulting from ERI, rather than the impact on the accrued liability" (p. 9). As noted above, the $\$ 2.3$ billion in additional liabilities was a product of "the increase in the present value of future benefits that resulted from ERI is $\$ 1.75$ billion, while the increase in accrued liabilities resulting from the ERI totaled $\$ 2.3$ billion" (ERI 2006, p. 9). Initial estimates of enrollment in the early-retirement program were 7,365 , but in reality, approximately 11,039 public 
employees bought into the program. Governor Rod Blagojevich (D) enhanced Ryan's initial impact of delaying pension payments when he signed Senate Bill 27 that allowed the state to "skip half its pension payments for two years and to stretch out some expenses approved under the previous governor, George Ryan" (McKinney 2015 para. 3). The cost of Governor Blagojevich's decision to push off payments added $\$ 6.8$ billion in unfunded liabilities.

The next decade brought the first attempt to curb unfunded pension liabilities and reduce the escalating effect of the fiscal crisis in this thirty-year period, dating back to Governor Thompson. In 2010, Governor Pat Quinn (D) signed a state law that "stopped automatic, compounded yearly cost-ofliving increases for retirees, extended retirement ages for current state workers, and limited the amount of salary used to calculate pension benefits" (Pearson \& Geiger 2015 para. 3). The Quinn reform legislation sparked controversy within state employee unions, who argued that since the state constitution mandates that pension benefits are contractually bestowed, the benefits cannot be "diminished" or "impaired." In 2015, the Illinois Supreme Court ruled that the Quinn reform law "clearly violated what's known as the pension protection clause in the 1970 Illinois Constitution" (Pearson \& Geiger 2015 para. 5).

The effects of this ruling weighed heavily into Governor Bruce Rauner's (R) Administration, whose tenure was plagued by an inability to pass a state budget. According to the Chicago Tribune, Governor Rauner attributed the budget impasse as a product of resistance from both the Democrat-controlled General Assembly and the lack of financial flexibility in reforming pension payments after "justices appeared to offer little in the way of wiggle room beyond paying what's owed, which likely would require a tax increase" (Pearson \& Geiger 2015 para. 9). Rauner, working with a Democrat-controlled General Assembly throughout the entirety of his governorship, successfully passed the first state budget in 2018 after three years without a budget. In seeking to deal with the judicial roadblock on reducing pension liabilities, Governor Rauner argued that Illinois Supreme Court's 2015 pension ruling "only reinforces his approach of getting voters to approve a constitutional amendment that would allow the state to move forward on common-sense pension reforms" (Pearson \& Geiger 2015 para. 10).

After the 2018 Illinois Gubernatorial election, Governor-elect J.B. Pritzker (D) inherited the state's behemoth pension debt, encompassed within " $\$ 130$ billion in underfunded liability (with) a $40 \%$ funded ratio" (Bauer 2018 para. 2). According to Forbes, Pritzker offered the beginning details of his potential pension reform outline through "flattening out the amortization table," noting a relationship to the Edgar Ramp in which contributions will be set "artificially low for the first 15 years of a 50-year amortization schedule" through "increased scheduled state contributions that conform, most years, anyway, to a somewhat reasonable inflationary increase (about 3\%)" (Bauer 2018 para. 6). If implemented, Forbes reports that "state contributions to pension funds and debt service on pension obligation bonds [would] constitute $27 \%$ of all state spending" within the entire operating budget. During the Gubernatorial campaign, Pritzker was vocal in his support to Tier II reform that changes the pension formula for new beneficiaries entering the pension pool in 2011, by implementing a "benefit cost curve" that "increases the vesting age and the retirement age, reducing the COLA, and capping benefit-eligible salary" (Bauer 2018 para. 7).

\section{CREDIT ANALYSIS}

In assessing the credit and investment quality of the State of Illinois, we conducted a two-pronged analysis using debt ratios and economic indicators. The purpose is to use internal metrics within Illinois that comprehensively outlines outstanding debt and unfunded liabilities under the state's responsibility and a regional inquiry into how the State of Illinois compares to other states within the Midwest region through economic indicators that express the fiscal health of the respective state.

\section{Debt Ratios}

The first debt ratio considered is debt-torevenue. The total primary government debt for Fiscal Year 2017 is $\$ 29,173,391,000$ and total primary government revenue is $\$ 69,797,000,000$, 
yielding a debt-to-revenue ratio for Fiscal Year 2017 of 41.8\% (State of Illinois Comptroller 2017). For Fiscal Year 2010, total primary government revenues were $\$ 59,834,000,000$ and expenditures were $\$ 69,848,000,000$; Total primary government debt was $\$ 28,843,970,000$ (Tropinka 2010, p. 7; p. 352).

Together, these numbers yield a primary government debt-to-revenue ratio of $48.2 \%$, which, when compared to the Fiscal Year 2017 ratio of 41.8\% shows the ratio is decreasing; however, after seven years, the total primary government debt has increased by $\$ 329,421,000$ or $1.1 \%$. The major factor behind the decreased debt-to-revenue ratio is the $\$ 9,963,000,000$, or $16.7 \%$, increase in revenue.

Turning to total primary government debtto-expenditure ratios, Fiscal Year 2010 yields a ratio of $41.3 \%$. Fiscal Year 2017 has total primary government expenditures of $\$ 79,658,000,000$, which yields a debt-to-expenditure ratio of $36.6 \%$ (State of Illinois Comptroller 2017). As stated above, total primary government debt increased between FY 2010-2017, thus the main reason for the decreasing ratios is the $\$ 9,810,000,000$ increase in expenditures.

As communicated in the Fiscal Year 2017 Comprehensive Annual Financial Report, total primary government debt as a percentage of personal income for FY2017 is 4.4\%; for Fiscal Year 2010, it is 5.43\% (State of Illinois Comptroller 2017. The total amount of primary government debt per capita for Fiscal Year 2017 is \$2,279; FY2010, \$2,254 (State of Illinois Comptroller 2017). Being the only debt ratio that increased since Fiscal Year 2010, we attribute this increase to the net outbound migration of citizens, leaving fewer people with a higher share of the state's debt. The comprehensive annual financial reports also contain general bonded ratios. In Fiscal Year 2017, the total general bonded debt as a percentage of personal income was 3.99\%, in Fiscal Year 2010, it was $5.01 \%$. The total amount of general obligation debt per capita for Fiscal Year 2017 was \$2,069; for Fiscal Year 2010, \$2,083 (State of Illinois Comptroller 2017).

\section{Economic Indicators}

The second part of our credit analysis compares economic indicators from the State of
Illinois with Midwest regional averages and individual average statistics from border states. The multiple economic indicators analyzed include gross domestic product (GDP) per capita, the unemployment rate as of October 2018, the net pension liability and funded ratio per specific state, and per capita personal income. In addition, we have provided data regarding the net outbound migration pattern of citizens from the State of Illinois.

The first economic indicator analyzed is GDP per capita. This economic indicator illustrates a state's total economic output divided by the number of citizens and adjusted for inflation; providing an estimate of the economic productivity per citizen (Amadeo 2018). According to WolframAlpha (2018), Illinois ranks second out of the Midwest states with a GDP per capita of $\$ 64,081$. In the region, the weighted average of the twelve Midwest states is $\$ 57,038$ per year per person with a median of $\$ 56,663$ per year per person in 2017 . Based on this data, Illinois has a significant margin above both the weighted average, at approximately $\$ 7,043$ per person per year, and the regional median at $\$ 7,418$ (WolframAlpha 2018). Because the GDP per capita indicates Illinois has a substantially higher domestic production than other Midwestern states, we can conclude that the State has a greater economic output when controlling for population. Furthermore, Illinois' GDP per capita indicates a higher standard of living level than in the Midwest overall and remains an economically viable location for businesses, which, in turn, results in stable and strong tax revenues bases that could be used for debt repayment. Amadeo (2018) mentions that GDP per capita is the best measurement of a state's standard of living because "it tells you how prosperous a country (or state) feels to each of its citizens" (para. 1).

The second economic indicator used for our credit analysis is the unemployment rate. Our reasoning behind the inclusion of this indicator is to illustrate the "percentage of unemployed workers in the total labor force (seeking employment)", which provides "insights into the economy's spare capacity and unused resources" (FocusEconomics 2018, para. 1). The unemployment data was last updated in October 2018. According to the Bureau of Labor 
Statistics (2018), the October 2018 unemployment rate for the State of Illinois was 4.2 percent. As compared to regional data, the Midwest average unemployment rate was 3.7 percent as of October 2018. Regional neighbors of Illinois - including Indiana, Iowa, and Wisconsin - have unemployment rates of 3.5 percent, 2.4 percent, and 3.0 percent, respectively as of October 2018 (Bureau of Labor Statistics [BLS] 2018). The primary takeaway from the unemployment rate economic indicator is that Illinois has the highest "percentage of total workforce who are unemployed and are looking for a paid job" (Business Dictionary 2018). As a result of Illinois' high unemployment rate as compared to the region, it can be concluded that Illinois may be exhibiting signs of a weakening economy.

The third financial indicator used for our credit analysis is net pension liability and pension funded ratio. The purpose for the inclusion of this financial indicator is to illustrate the "difference between the total pension liability (the present value of projected benefit payments to employees based on their past service) and the assets (mostly investments reported at fair value) set aside to pay current employees, retirees, and beneficiaries"

(AccountingWeb [AW] 2012, para. 9). In Fiscal Year 2017, Illinois had a total pension liability of $\$ 214.478$ billion, assets of $\$ 85.386$ billion, which in turn, created a net pension liability of $\$ 129.091$ billion, and a funded ratio of 39 percent (Commission on Government Forecasting \& Accountability: Illinois General Assembly 2018). Illinois falls greatly behind its Midwestern neighbor-states when compared to Indiana, which has $\$ 16.181$ billion in net pension liability and a funded ratio of 86.3 percent (Indiana Public Retirement System 2017), Iowa with $\$ 6.661$ billion and 82 percent (Iowa Public Employees' Retirement System 2017), and Wisconsin which has an $\$ 824$ million net pension liability and a 99.1 percent funded ratio (Wisconsin Department of Employee Trust Funds 2017).

This economic indicator reveals the sizeable difference in the accumulation of pension liabilities between Illinois' net pension liability and its regional neighbors, as well as a significantly lower funded ratio compared to border states Indiana, Iowa, and
Wisconsin.

The fourth economic indicator used in our analysis is per capita personal income. The purpose of its inclusion as an economic indicator within our analysis is to show the average amount of stock each individual has within the State of Illinois. According to the 2017 Illinois Comprehensive Annual Financial Report (CAFR), the per capita personal income in 2016 was \$51,187 (Illinois CAFR 2017). During that same year within the Midwest, Indiana had a per capita personal income of $\$ 43,097$, Iowa had a per capita personal income of $\$ 46,794$, and lastly, Wisconsin with a $\$ 46,762$ per capita personal income (Indiana CAFR 2017; Iowa CAFR 2017; Wisconsin CAFR 2017). In comparing per capita personal income with Midwestern neighbor-states, this indicator allows for the comparison of wealth between individuals in different states. Thus, Illinois has a significantly larger per capita personal income than its Midwestern neighbors, which means that the average income per person within the State of Illinois, effectively, creates larger income tax revenues to the State for the purposes of debt repayment.

The fifth and final measure is a demographic indicator used in our analysis - the net outbound migration statistics - that highlights the mass exodus from the State of Illinois. Our reason for including this indicator within our greater analysis is to underline the significant outbound migration out of Illinois which can lead to a decrease in tax revenue if tax rates are not increased. According to the Chicago Tribune, approximately 33,703 citizens left the State of Illinois in 2017, affirming "Illinois' fourth year in a row of population decline" ("Genesis of the Illinois Exodus" 2018, para. 4). Furthermore, the overall trend of outbound state-to-state migration "grew from 68,204 in 2013 to 93,704 in 2014" (para. 7), and growing again in 2015 with 106,544 departures and 109,941 in 2016; the most recent outbound migration figure in 2017 was 114,779 . The startling departure figures were confirmed by moving companies United Van Lines and North American Van Lines who report that "Illinois was the nation's top outbound state in 2017" (para. 8). The Chicago Tribune elaborates further on this point of distress stating the 
incentive for outbound migration is based on individuals and families "unhitching their futures from a state awash in debt, mired in political dysfunction and hobbled by weak job growth" (para. 2).

\section{BONDS}

\section{Bond \#1}

The first bond series analyzed is the State of Illinois General Obligation (GO) Bonds, Taxable Series of January 2010. According to the official statement, the par value of the bonds is $\$ 3,466,000,000$. The primary use of bond proceeds was to be "deposited into the Pension Contribution Fund of the State" (State of Illinois 2010, p. 4). The application of the bond proceeds is allocated so that $\$ 3,451,606,316.85$ will be spent on funding or reimbursing pension contributions, $\$ 13,666,683.15$ for underwriter's discount, and $\$ 727,000$ on issuance expenses. As a result of the general obligation nature of the issuance, the bonds are under direct responsibility of repayment by the State and are entrusted by "law (with) the full faith and credit of the State is pledged for the punctual payment of interest on the Bonds as interest becomes due and for the punctual payment of the principal thereof at maturity, or any earlier redemption date, and premium, if any" (p. 5). Furthermore, the Bond Act requires that the repayment of these GO bonds "are irrepealable until all GO Bonds issued under the Bond Act, including the Bonds, have been paid in full" (p. 5). The Constitutional provisions regarding long-term borrowing, and thus concerning the 2010 GO Bonds, includes Section 9(a) of Article IX of the State Constitution, which states bonds or other evidence of indebtedness which are secured by "the full faith and credit of the State or are required to repaid directly, or indirectly, from tax revenues," and Section 9(b) of Article X, which includes verbiage detailing that state debt for specific purposes may be "incurred or the payment of State or other debt guaranteed in such amounts" as may be provided either in a legislation passed by the General Assembly or in a law approved by a majority of the "electors voting on the question at the next general election following passage" (p. 7-8).
The maturity schedule of the bonds comprises redemption dates of January 1st ranging from 2011 to 2015 , with fixed principal payments of $\$ 693,200,00$ (State of Illinois, Maturity Schedule section 2010). As of January 1, 2015, the secondary market data for this bond issue shows significant instability. From January 2010 to approximately July 2011, the lifetime price trend for the issue fluctuated above and below par; par being the price the government will pay the holder for each individual bond once it reaches maturity. For this issue, the par value is $\$ 5,000$ (State of Illinois 2010). After July 2011, the price remained above par until its final traded date of December 23, 2014 (Electronic Municipal Market Access [EMMA] 2018). More specifically, the most significant instances in which the price of the bond dipped below par value occurred in February 2010, May 2010, July 2010, December 2010 through May 2011, July 2012, July 2013, September 2013, and July 2014. The drop in price between December 2010 through May 2011 could be due to market reactions to the refusal by the Illinois Supreme Court on Quinn's reforms seeking structural changes to pension beneficiary payments (EMMA 2018). Despite such drops, it appears that the bond remained popular as indicated over one hundred pages of trading data related to the bond on EMMA from its first sale on December 20th, 2010, until its final maturity on January 1st, 2015 (EMMA 2018). This shows that investors were seeking to purchase the bond, thus indicating demand for ownership of GO debt, as well as potential optimism on the future financial governance of the state.

The long-term ratings of this bond issuance include an A2 with a Negative Outlook from Moody's, an A with a negative watch from Fitch Ratings, and an A+ with Negative Outlook from Standard \& Poor's. According to Moody's, the ratings rationale explaining the Negative Outlook for the multi-billion dollars of general obligation debt indicates "signs of financial stress have emerged or intensified since the last downgrade," further enhanced by a "debt burden (that) is expected to escalate because of issuance for capital projects and pension contributions" (Hampton 2010, Opinion section, para. 2). The credit strengths of this bond 
issuance include:(i) "sovereign powers to raise revenues and reduce expenditures," (ii) "statutory prioritization of debt service payment from state revenues," (iii) a "diverse economy with higher-thanaverage wealth levels," (iv) "limited variable-rate debt exposure," and (v) "agency and trust funds equivalent to about $25 \%$ of annual budget" (para. 3 ). The credit challenges of the bond issuance include: (i) "widening negative fund balances which reflect systematic payment delays," (ii) "very large unfunded pension liabilities and failure to approve measures for current-year funding," (iii) "vulnerability to weak economic recovery," and (iv) "failure to enact recurring measures to balance the budget" (para. 4) Lastly, the future outlook of the GO bond issuance regarding potential ratings upgrades includes enacting annual budgetary measures that "improve financial operations and prospects for structural balance," strengthening levels of budgetary reserve and fund balance, progressing towards paying down "unfunded obligations for public employee pensions and other retiree benefits," and lastly, significant reduction in the lump sum of year-end unpaid bills - i.e., accounts payable (Hampton 2010, Outlook section, para. 2). On the other hand, the GO bond could face a future downgrade if Illinois fails to "meet statutory pension contribution requirements" through the greater issue of not "approving pension bonding legislation," a turn of the economy which would enhance economic pressures, the inability from General Assembly to enact "significant recurring measures to address structural imbalance," an increase in negative GAAP fund balance, or limited market access (para. 3).

\section{Bond \#2}

The second bond series to be analyzed is the General Obligation Refunding Bonds, Series of September 2018, totaling \$965,770,000 with Series September 2018A totaling $\$ 641,160,000$ and September 2018B totaling $\$ 324,610,000$ (State of Illinois 2018). The 2018A bond proceeds will be used to "(i) refund all of the outstanding maturities of the State's outstanding Variable Rate General Obligation Bonds, Series B of October 2003, (ii) pay necessary termination payments to the providers of interest rate exchange agreements in connection with such refunding and (iii) pay costs associated with the issuance of the Series 2018A bonds" (State of Illinois 2018, p. i). As noted in the September 2018 official statement, the Series 2003B Bonds are the only outstanding variable rate general obligation bonds Illinois has. Series 2018B proceeds are used to “(i) refund certain general obligation bonds of the State and (ii) pay costs associated with the issuance of the Series 2018B" (p. 5). Both Series A and B reach maturity in 2033, are secured by the full faith and credit of Illinois, and are contain a call-option after October 1, 2028. The Bond Act requires the creation of a separate fund within the State Treasury to be used for repayment with the State Treasurer and Comptroller required to transfer from the General Revenue Fund the amount sufficient to pay the principal, interest, and redemption premiums, to meet the payment date each year. The Bond Act also requires the governor to appropriate "necessary and sufficient" funds to pay the debt service in each annual State Budget (p. iii).

This issue has been rated Baa3 with a Stable Outlook from Moody's; BBB- (Stable Outlook) from S\&P Global Ratings; and BBB (Negative Outlook) from Fitch Ratings Inc (State of Illinois 2018). The only ratings report on this issue that could be obtained is from Moody's. They state that despite Illinois having a "diverse, large, and comparatively wealthy" economic base, Illinois' weak governance has caused the state to run a deficit which generated unpaid bills that the state has relied on debt financing to pay (Moody's Investors Service [MIS] 2018, para. 2). Despite this, Moody's provides three solutions that would lead to a credit rating upgrade: (i) adoption of a comprehensive plan to fix pension liabilities, (ii) decreasing the backlog of unpaid bills without using long-term debt financing, (iii) enactment of a sustainable balanced budget (MIS 2018). If Illinois continues to let the backlog of bills increase, continues contributing less than is sufficient to cover the pension liabilities, or assumes substantial debt or pension liabilities of local governments, the state would likely see its credit downgraded again.

Since its issuance in September 2018, this bond series has seen some trade activity. None of the 
trades on the secondary market have been below parvalue. This highlights the positive feeling of investors that Illinois is moving towards potentially correcting some of its problems.

\section{Bond Summary}

In reflecting on both general obligation bonds, the primary takeaway is the decrease in credit ratings over time from the issuance in 2010 to the latter in 2018. The 2010 GO Bond experienced price drops on the secondary market below par throughout its fiveyear lifespan; however, the bond maintained a popular and sought-after option to investors. Eight years later, the 2018 GO Bond saw stark rating decreases to one level above junk. As stated in Moody's Ratings Action report, the credit downgrade is a result of continued fiscal mismanagement, continuing accumulation of unfunded pension liabilities, and the inability to pass a balanced budget. As noted by 2018 Moody's report, the comprehensive credit rating reduction from 2010 to 2018 is indicated by Illinois' weak governance and fiscal management that continually requires "the state to run a deficit which generated unpaid bills that the state has relied on debt financing to pay" (MIS 2018, para. 2).

\section{SOLUTIONS}

\section{Mandated Funding Ratio}

Currently, the Edgar Ramp's funded ratio projections to meet the goal of $90 \%$ funding by 2045 only serve as guidelines for the state government. We propose the current Fiscal Year 2018 Edgar Ramp projections be turned into law. Each year, the state government will have to ensure the pension system is funded at least equal to what the 2018 projection has the funded ratio being. This solution will effectively be forcing the state to increase the level of contributions to the pension system each year and prevent the current problem of the state government not contributing a sufficient amount to offset the growth of unfunded liabilities.

Additionally, mandating the funding ratios projections would serve to meet the first criteria outlined in the Moody's report for establishing a comprehensive plan to fix the unfunded pension liabilities. This would increase the likelihood of upgrading Illinois' credit rating and lowering borrowing costs, while also adhering to our main goal with this solution, which is to decrease unfunded liabilities. This solution, however, has a potential negative consequence - when investment returns are not at or above the expected level, the state would be forced to account for the difference. In those years, this would mean the state might have to decrease funding for other services and projects or increase tax rates to bring in more revenue.

\section{Balanced Budget Amendment}

Since 2000, in terms of total primary government revenue to total primary government expenditures, Illinois has failed to pass a balanced budget. Figure 2 in the Appendix shows the total primary government expenditures-to-revenue ratios from Fiscal Year 2017 to Fiscal Year 1993. As has been the case with the lack of state contributions to the pension system, Illinois has made up for the lack of revenues by issuing debt. Continuing down this path of passing unbalanced budgets will lead to a downgrade by Moody's as stated in their rationale for the ratings given to the September 2018 General Obligation Refunding Bonds.

Having a balanced budget amendment will not only prevent Illinois from continuing the trend of spending more than they receive in revenue but will also ease investors' concerns that Illinois will continue deficit spending. By passing a balanced budget amendment and mandating funding ratios, the odds of receiving a credit rating upgrade will be increased since two of the three reasons Moody's provided for a possible upgrade would be satisfied. However, as is the case for the mandated funded ratio, there are tradeoffs.

By mandating that expenditures do not exceed revenues, Illinois will have to cut spending or increase tax rates. Cutting spending will entail providing citizens with fewer services or removing funding for infrastructure, whereas increasing tax rates will increase the burden that is already causing citizens to move out-of-state. Yet, for more than the last decade, Illinois' elected officials have shown their inability to pass a balanced budget. The value of 
this amendment could not be further increased.

The most important characteristic of the balanced budget amendment is enforceability. The National Conference of State Legislatures (NCSL) traditionally reports 49 states as having a balanced budget requirement - Vermont being the exception (NCSL 2010). Of the 49 states reported as having a balanced budget requirement only 22 states report having a mechanism to enforce the requirement. According to the NCSL, three characteristics determine whether or not a state has a balanced budget requirement and a state only needs one of these three - (i) the governor is required to submit a balanced budget; (ii) the enacted budget is required to be balanced; or (iii) the state government cannot carry over a deficit from one year to the next (NCSL 2010). The National Association of State Budget Officers (NASBO), whose report was cited as determining the three characteristics for having a balanced budget requirement by the NCSL, splits 'the enacted budget is required to be balanced' characteristic into two separate characteristics - (i) if the legislature is required to pass a balanced budget; and (ii) if the budget signed by the governor is required to be balanced (NASBO 2015).

Illinois has two of the four characteristics for balanced budget requirements according to NASBO - the governor is required to submit a balanced budget to the legislature, and the legislature is required to pass a balanced budget both mandated by the state's constitution and statutory law (NASBO 2015). Illinois does not require that the final budget the governor signs be balanced, nor is the government prevented from carrying over a deficit into the next fiscal year. If the legislature is required to pass a balanced budget, however, that would generally necessitate that the governor would be signing a balanced budget; but Illinois' balanced budget requirements have several issues. First, Illinois' constitution only requires that "proposed expenditures shall not exceed funds estimated to be available for the fiscal year as shown in the [governor's] budget," and, the General Assembly cannot make appropriations for a fiscal year that "exceed funds estimated by the General Assembly to be available during that year" (Illinois Const. Article
VIII, §2, cl. A.; cl. B). Though Illinois’ constitution requires the governor to propose a balanced budget, and the legislature makes appropriations less than or equal to estimated revenue, there is no enforcement mechanism to prevent actual expenditures from exceeding actual revenues during the fiscal year (Illinois Const. Article VIII, §2), nor is there an enforcement mechanism in the "State Budget Law" (Illinois Compiled Statutes, § 20 Article 50/1-40).

Without the ability to ensure that actual expenditures do not exceed actual revenues, the balanced budget requirement is meaningless. We propose two options for enforceability. First, to make the governor himself responsible for implementing necessary changes to balance the budget if actual expenditures exceed actual revenues. This is a viable option because the governor alone would be responsible for deciding what expenses to cut or how to increase revenue. Also, the public would be able to focus their attention on one person and hold him/her accountable in future elections if he/she is unwilling to make changes or if the public disagrees with the changes.

The second option is to have a legislativeexecutive, nonpartisan commission established, with the majority and minority leaders from both houses and the governor comprising the committee. The committee as a whole would be responsible for making the necessary changes to ensure the budget is balanced. This option would ensure bipartisan support on the necessary changes being made but has the tradeoff of potentially leading to nothing being accomplished. The potential for infighting could be offset by the public holding both sides to blame for the lack of a balanced budget if nothing gets done. To ensure that neither option fails, the third provision would entail that if the committee or governor (whichever option is in the balanced budget amendment) fails to maintain a balanced budget, the Illinois Supreme Court would step in and mandate either that expenses are cut or revenues are increased, predicated on the State's fiscal needs, as would be suggested by the Commission on Government Forecasting \& Accountability. 


\section{Expanded Sales Tax Base}

Our third and final solution is to expand the sales tax base to include services. As of 2017, Illinois includes seventeen services within its sales tax base, twelve of which are related to public utilities, which fall under three statutes - Electricity Excise Tax, Telecommunications Excise Tax, and the Natural Gas Revenue Tax (CGFA 2017). The other five taxed services are prepaid calling cards, photo processing, software-to-software services, hotel/motel rentals, vehicle rentals, coin-operated amusement machines, and materials used in repairs or installations. Our proposal would make Illinois' sales tax base similar to Iowa's, which is the broadest in the Midwest, by taxing an additional 81 services (CGFA 2017, Table 1, p. 11). The CGFA estimates this move would bring in between $\$ 1.2$ billion and $\$ 2.9$ billion of additional revenue if fully implemented by FY2020. The top three potential services for tax revenue in Fiscal Year 2018 are - storage of raw agricultural products, bringing in between $\$ 101.6$ million and \$2.031 billion; investment counseling, generating between $\$ 389$ million and \$926 million; and employment and executive search agencies, which would account for between $\$ 35.8$ million and $\$ 482.9$ million (CGFA 2017, Table 2, p. 12-14).

Expanding the sales tax base to include services would admittingly create both benefits and consequences. If Illinois expanded the sales tax base and pledged the additional revenue to go towards the pension liabilities in Fiscal Year 2018 - assuming the CGFA's estimates are true and Illinois would receive $\$ 2.04$ billion in additional revenue - the unfunded pension liability would have increased by $\$ 2.346$ billion $^{1}$ instead of the $\$ 4.386$ billion increase in total unfunded liabilities ${ }^{2}$ that actually happened between FY2017 and FY2018. The tradeoff is that increasing taxes can increase prices (CGFA 2017; CGFA, 2018). In the case of making the storage of agricultural products taxable, this can cause the cost of consumer food to increase. Making employment and executive search agencies taxable could potentially make the service more expensive than

\footnotetext{
${ }^{1} \$ 2.346$ billion obtained by subtracting $\$ 2.04$ billion from $\$ 4.386$.
}

some people might be able to afford and thereby make employment more difficult to find.

\section{CONCLUSION}

For all its faults and through all the missteps, Illinois has not yet become a failed state. Its situation is salvageable but there is no golden goose, no magical cure-all to instantly fix the unfunded pension liabilities. The solutions we propose will not individually fix the pension system, but together they will correct individual problems that have together created and maintained the pension crisis. The tradeoffs may seem heavy, but the consequences of doing nothing far outweigh the tradeoffs of the solutions. After all, it was the unwillingness of elected officials to make the tough, but fiscally smart choices, that created this crisis in the first place. If Illinois continues contributing insufficient payments into the pension system, delaying pension payments, and running annual budget deficits, debt will become the State's master and the general assembly will exist solely to answer to its creditors.

Assigning blame to one group responsible for creating this problem neglects the role others have played. The first culprit is the general assembly, which is supported by current Illinois Supreme Court Chief Justice Lloyd A. Karmier who said, "the General Assembly may find itself in crisis, but it is a crisis which other pension systems managed to avoid and it is a crisis for which the General Assembly itself is largely responsible" (Pearson \& Geiger 2015, para. 7). Yet, laying this problem solely at the feet of the General Assembly neglects the role previous governors have played. Governor Thompson increased the cost-of-living-adjustment and, as a result, pension liabilities; Governor Edgar created the 'Edgar Ramp' that allowed Illinois to underfund the pension system with no way to enforce the projected funding levels; Governor Ryan sought to avoid laying off workers and endangering his re-election chances by incentivizing early retirement, and further increased pension liabilities; Governor Blagojevich skipped half of all pension payments for two years;

\footnotetext{
2 Obtained by subtracting \$129.091 billion in total unfunded liabilities from FY2017 (CGFA) from the $\$ 133.478$ billion in total unfunded liabilities from FY2018.
} 
Governor Quinn, though he tried one method of correcting the previous mistakes, failed to keep trying once his first solution was deemed unconstitutional; Governor Rauner allowed Gov. Quinn's failure to prevent him from making any attempts at reform; lastly, current Gov. Pritzker is willing to bet that the Edgar Ramp, which has played a large role in creating the current crisis, is still the best method of correcting the crisis.

At each step, however, the General Assembly allowed each governor to make these mistakes and worsen the crisis; the governors continued making these mistakes because they were elected and reelected to their positions. The most direct and natural source of the blame can then be attributed to the taxpayers of the State of Illinois, who by voting for the governor and members of the General Assembly, have validated the presence of fiscal mismanagement for decades. But the decisions of the voters are not one we can, nor want to, regulate. After all, it is the elected officials who have had the final say in fixing or worsening the pension crisis, and it is in regulating the decisions of the elected officials, that our solutions will be most effective.

Instead of giving future generations the ability to prosper, future generations have been burdened with a back-breaking level of pension debt. Our solutions will gradually lift the debt burden from their shoulders and allow them to enjoy all that Illinois has to offer. Furthermore, as less of the General Fund goes towards the pension system, the freed revenue can be used towards enhancing the quality-of-life and attracting citizens and businesses back to the state. Then, Illinois can serve as a symbol of resurrection for the nation.

\section{NOTES}

In our research, we had difficulty collecting ratings information from Standard \& Poor's and Fitch Ratings regarding both general obligation bond issuances. That being said, we used Moody's as a primary source of ratings information; however, we faced challenges receiving more information expanding on the General Obligation Taxable Series January 2010 bonds because Moody's had reserved the information to advanced users (i.e. paid subscribers) of the website. So, in order to provide an overview of the 2010 GO Bond, we cited a 2010 Moody's article entitled 'Moody's Revises Illinois' Outlook to Negative from Stable, Indicating Risk of Further Deterioration" to further elaborate on the Negative Outlook concerning the lump sum \$25 billion in $\mathrm{GO}$ bonded debt.

\section{LITERATURE CITED}

Amadeo, K. 2018. Real GDP Per Capita, How to Calculate It, and Data Since 1947. The Balance. https://www.thebalance.com/real-gdp-per-capita-how-tocalculate-data-since-1946-3306028

Bauer, E. 2018. Pritzker, Rauner and Illinois' Pension Trouble. Chicago Tribune.

https://www.forbes.com/sites/ebauer/2018/10/17/pritzkerrauner-and-illinois-pension-trouble/\#bb7a6657b419

Budget Processes in the States. 2015. National Association of State Budget Officers. https://higherlogicdownload.s3.amazonaws.com/NASBO/ 9d2d2db1-c943-4f1b-b750-

0fca152d64c2/UploadedImages/Budget\%20Processess/20 15_Budget_Processes_-_S.pdf

Class-I Railroads, The Industry Standard. 2018. American-Rails.com. https://www.americanrails.com/class-i-railroads.html

Comprehensive Annual Financial Report for the Fiscal Year Ended June 30, 2017. 2017. Indiana Public Retirement System. https://www.in.gov/inprs/files/2017_INPRSCAFRBookW eb.pdf.

Editorial: "Genesis of the Illinois exodus." 2018. Chicago Tribune.

https://www.chicagotribune.com/news/opinion/editorials/c t-edit-exodus-census-illinois-chicago-20180426story.html

GASB's New Pension Standards Now Available. 2018. AccountingWeb.

https://www.accountingweb.com/aa/standards/gasbs-newpension-standards-now-available

Hampton, E. 2010. Moody's Revises Illinois' Outlook to Negative from Stable, Indicating Risk of Further Financial Deterioration. Moody's Investors Services. 
https://www.moodys.com/research/MOODYS-REVISESILLINOIS-OUTLOOK-TO-NEGATIVE-FROMSTABLE-INDICATING-RISK-Rating-Update-RU_16641113

Illinois Comprehensive Annual Financial Report for Fiscal Year Ended June 30, 2017. 2018. State of Illinois. https://illinoiscomptroller.gov/financial-data/find-areport/comprehensive-reporting/comprehensive-annualfinancial-report-cafr/fiscal-year-2017/.

Illinois Const. Article VIII, $\S 2$.

http://www.ilga.gov/commission/lrb/conent.html

Illinois State Retirement Systems: Financial Condition as of June 30, 2017. 2018. Commission on Government Forecasting \& Accountability: Illinois General Assembly. http://cgfa.ilga.gov/Upload/FinConditionILStateRetiremen tSysMar2018.pdf

Illinois Rail Facts. 2016. Illinois Department of

Transportation.

http://www.idot.illinois.gov/Assets/uploads/files/Transpor tation-System/Fact-Sheets/Rail\%20Facts_041216.p

Illinois State Retirement Systems: Financial Condition as of June 30, 2012. 2013. Commission on Government Forecasting \& Accountability: Illnois General Assembly. http://cgfa.ilga.gov/Upload/FinCondILStateRetirementSys FY2012Feb2013.pdf

Klutz, T. 2017. Indiana Comprehensive Annual Financial Report: 2017. State of Indiana.

https://www.in.gov/auditor/files/Entire\%202017\%20CAF R.pdf

McKinney, D. 2015. The Illinois Pension Disaster: What Went Wrong?. Crain's Business Chicago. https://www.chicagobusiness.com/static/section/pensions. html

Mendoza, S. 2017. Illinois Comprehensive Annual Financial Report: 2017. State of Illinois.

https://illinoiscomptroller.gov/financial-data/find-areport/comprehensive-reporting/comprehensive-annualfinancial-report-cafr/fiscal-year-2017/

Midwest Economy Labor Force Statistics. 2010. Bureau of Labor Statistics: Midwest Information Office. https://www.bls.gov/regions/midwest/data/xgtables/ro5xg02.html
Midwest States GDP Per Capita. 2018. WolframAlpha. https://www.wolframalpha.com/input/?i=midwest+states+ GDP+per+capita

NCSL Fiscal Brief: State Balanced Budget Provisions. 2010. National Conference of State Legislatures. http://www.ncsl.org/documents/fiscal/StateBalancedBudg etProvisions2010.pdf

Pearson, R., Geiger, K. 2015. Illinois Supreme Court rules landmark pension law unconstitutional. Chicago Tribune. https://www.chicagotribune.com/ct-illinois-pension-lawcourt-ruling-20150508-story.html

Pierog, K. 2017. Illinois' credit rating stays investment grade with Fitch. Reuters.

https://www.reuters.com/article/us-illinois-ratingsfitch/illinois-credit-rating-stays-investment-grade-withfitch-idUSKBN1A22C0

Ratings Action: Moody's assigns Baa3 to Illinois' 2018 GO Refunding Bonds; Outlook Stable. 2018. Moody's Investors Service.

https://www.moodys.com/research/Moodys-assigns-Baa3to-Illinois-2018-GO-refunding-bonds-outlook--

PR_904713089

FY2017 Comprehensive Annual Financial Report. 2017, p.ii. Iowa Public Employees' Retirement System. https://www.ipers.org/sites/default/files/CAFR\%20FY201 7.pdf.

Report on the 90\% Funding Target of Public Act 88-0593. 2006. Illinois Commission on Government Financing and Accountability.

http://cgfa.ilga.gov/Upload/Funding_PA_88-0593.pdf

Service Taxes: 2017 Update. 2017. Commission on Government Forecasting \& Accountability: Illinois General Assembly. http://cgfa.ilga.gov/Upload/ServiceTaxes2017update.pdf

State of Illinois Comptroller. 2017. Illinois

Comprehensive Annual Financial Report for Fiscal Year Ended June 30, 2017, p. 374-375.

https://illinoiscomptroller.gov/financial-data/find-areport/comprehensive-reporting/comprehensive-annualfinancial-report-cafr/fiscal-year-2017/

Comprehensive Annual Financial Report (CAFR). 2018. State of Illinois Comptroller. 
https://illinoiscomptroller.gov/financial-data/find-areport/comprehensive-reporting/comprehensive-annualfinancial-report-cafr/

Bond Ratings. 2018. State of Illinois Comptroller. https://illinoiscomptroller.gov/financial-data/fiscal-focusblog/bond-ratings/.

State of Illinois General Obligation Bonds Taxable Series of January 2010. 2018. Electronic Municipal

Market Access (EMMA).

https://emma.msrb.org/Security/Details/A99238F2084656 E9624958A84EB749932

State of Illinois General Obligation Bonds Taxable Series of January 2010. 2010. State of Illinois.

https://www2.illinois.gov/sites/capitalmarkets/Documents/ Official\%20Statements/Official\%20Statement\%20GO\%2 0Taxable\%20BABS\%202010-4.pdf

State of Illinois General Obligation Refunding Bonds, Series of September 2018. Electronic Municipal Market Access (EMMA). https://emma.msrb.org/ES1194130ES933263-ES1334194.pdf.

State of Illinois. 2006. Report on the Cost and Savings of the State Employees' Early Retirement Incentive Program. http://cgfa.ilga.gov/Upload/2006_JUNE_ERI_Report.pdf

Topinka, J. 2010. Comprehensive Annual Financial Report: Fiscal Year Ended June 30, 2010. State of Illinois. Retrieved from https://illinoiscomptroller.gov/LedgerTemp/assets/File/CAFR/CAFR\%202010.pdf
Unemployment rate. 2018. Business Dictionary. http://www.businessdictionary.com/definition/unemploym ent-rate.html

What is the Unemployment Rate? 2018. FocusEconomics. https://www.focus-economics.com/economicindicator/unemployment-rate

Wisconsin Comprehensive Annual Financial Report: 2017, p.228. 2017. State of Wisconsin. https://doa.wi.gov/DEBFCapitalFinance/2017/2017_CAF R_Linked.pdf

Wisconsin Retirement System Financial Report: Calendar Year 2016, p.5. 2017. Wisconsin Department of Employee Trust Funds.

https://etf.wi.gov/publications/16et8600/direct.

15 Ill. Comp. Stat. $§ 20$ Article 50/1-40.

http://www.ilga.gov/legislation/ilcs/ilcs4.asp?DocName $=0$ 01500200HArt\%2E+50\&ActID=186\&ChapterID $=4 \&$ Seq Start $=500000 \&$ SeqEnd $=-1$

2016 North American Top 50 airports. Airports Council International-North America (ACI-NA). https://airportscouncil.org/intelligence/north-americanairport-traffic-reports/north-america-airport-traffic-annualreports/ 


\section{APPENDIX}

\section{Edgar Ramp Pension Funding Projection and Actual Pension}

\section{Funding}

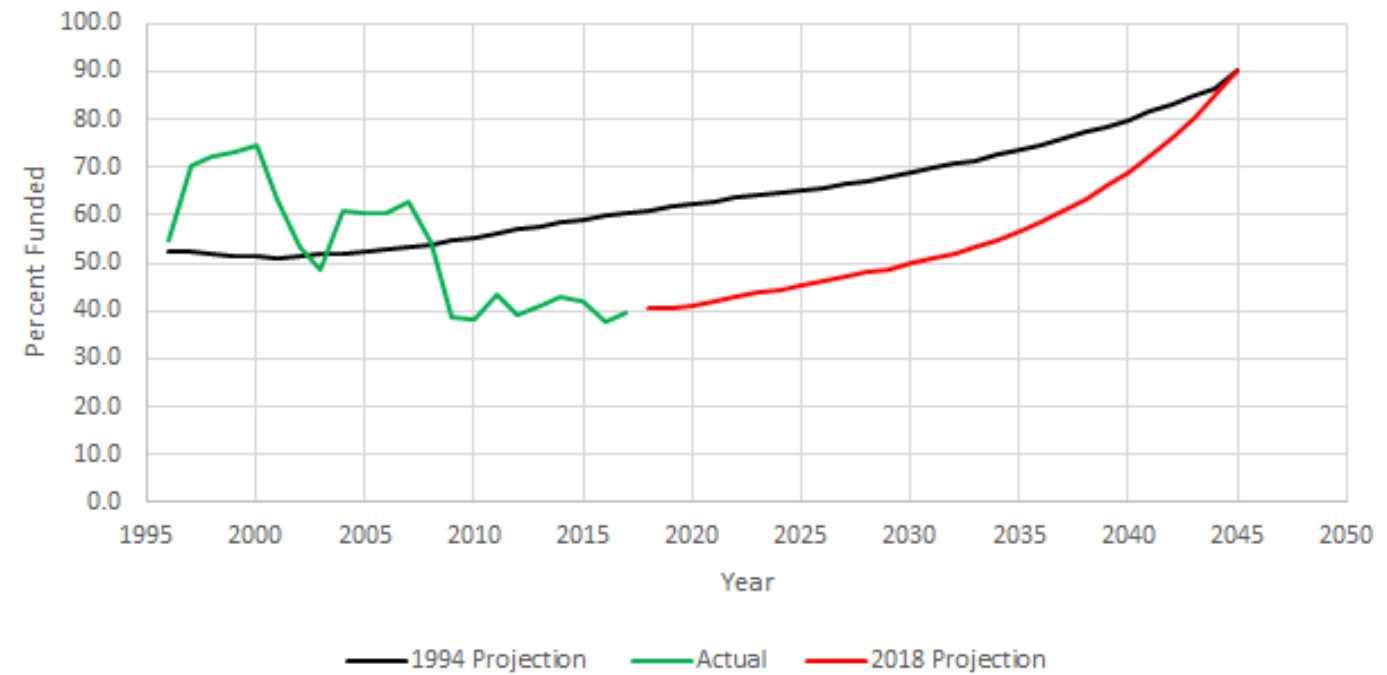

Figure 1. Edgar Ramp pension funding projecting and actual pension funding. Data for pension funding from the Illinois Commission on Government Financing and Accountability (2006; 2017).

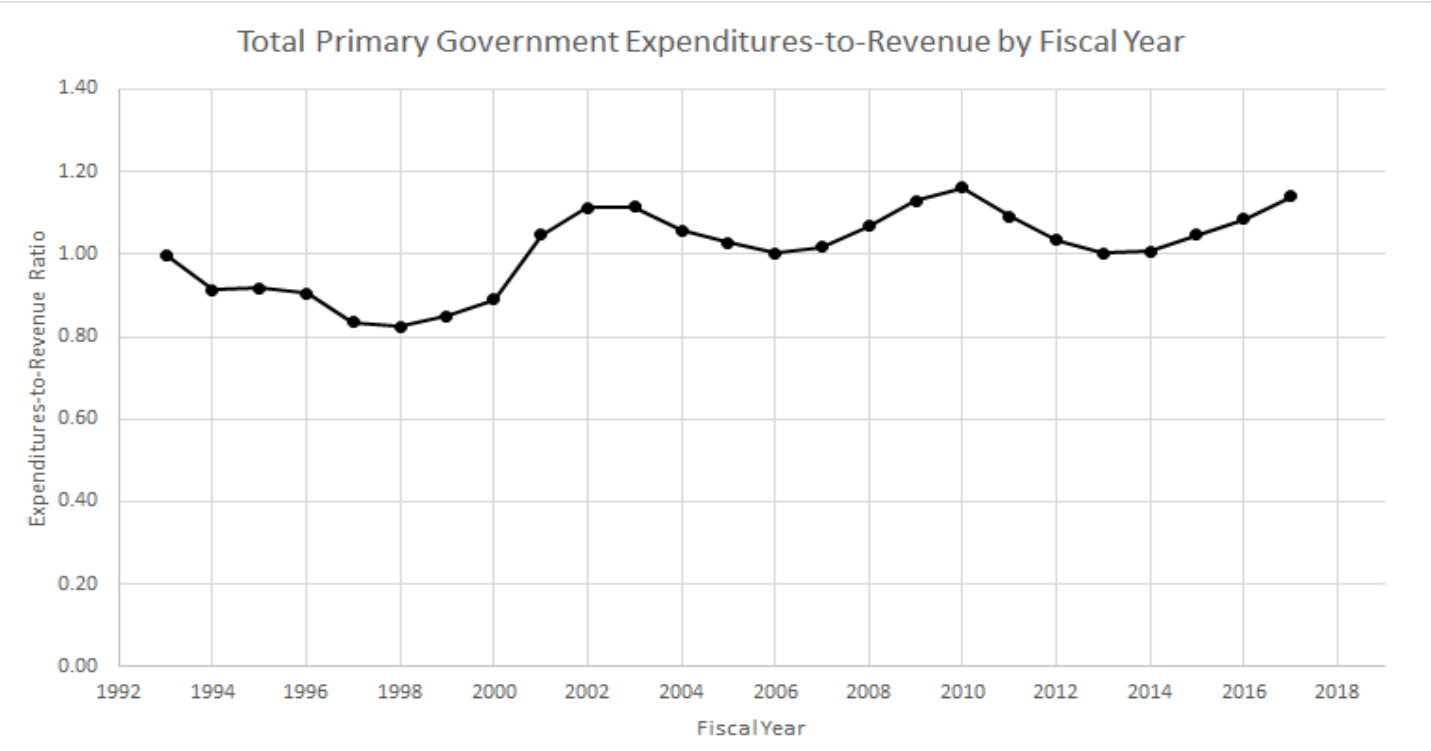

Figure 2. Total Primary Government Expenditures-to-Revenue by Fiscal Year. Data gathered from Comprehensive Annual Financial Report (CAFR), State of Illinois Comptroller (2018).

*In FY2006, Total Primary Government Expenditures exceed Total Primary Government Revenues by $\$ 137,000,000$; the expenditure-to-revenue ratio is not 1.00 exactly, but 1.0027 .

**In FY2013, Total Primary Government Expenditures exceed Total Primary Government Revenues by $\$ 114,000,000$; the actual expenditure-to-revenue ratio is 1.0016 . 
Total Unfunded Pension Liabilities, 1995-2045

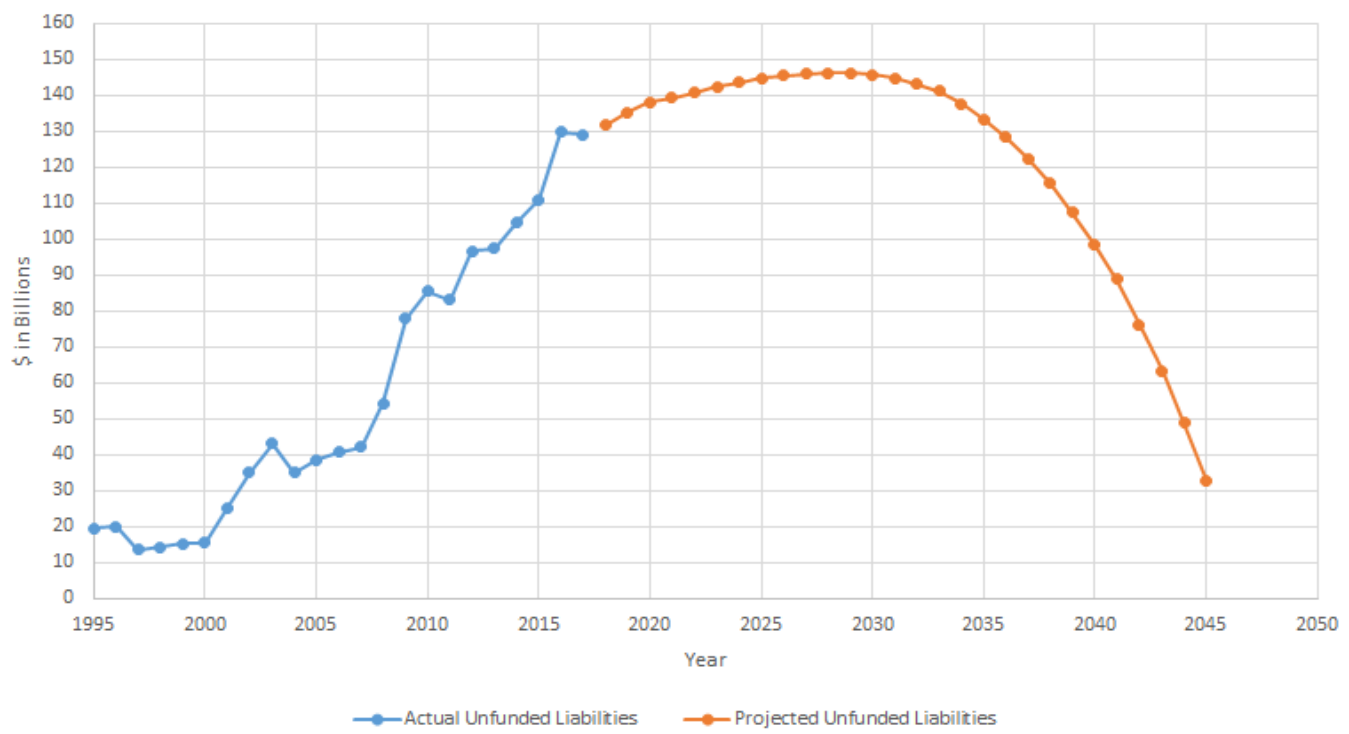

Figure 3. Total Unfunded Pension Liabilities, 1995-2045. Data gathered from the Illinois Commission on Government Financing and Accountability (2006; 2018).

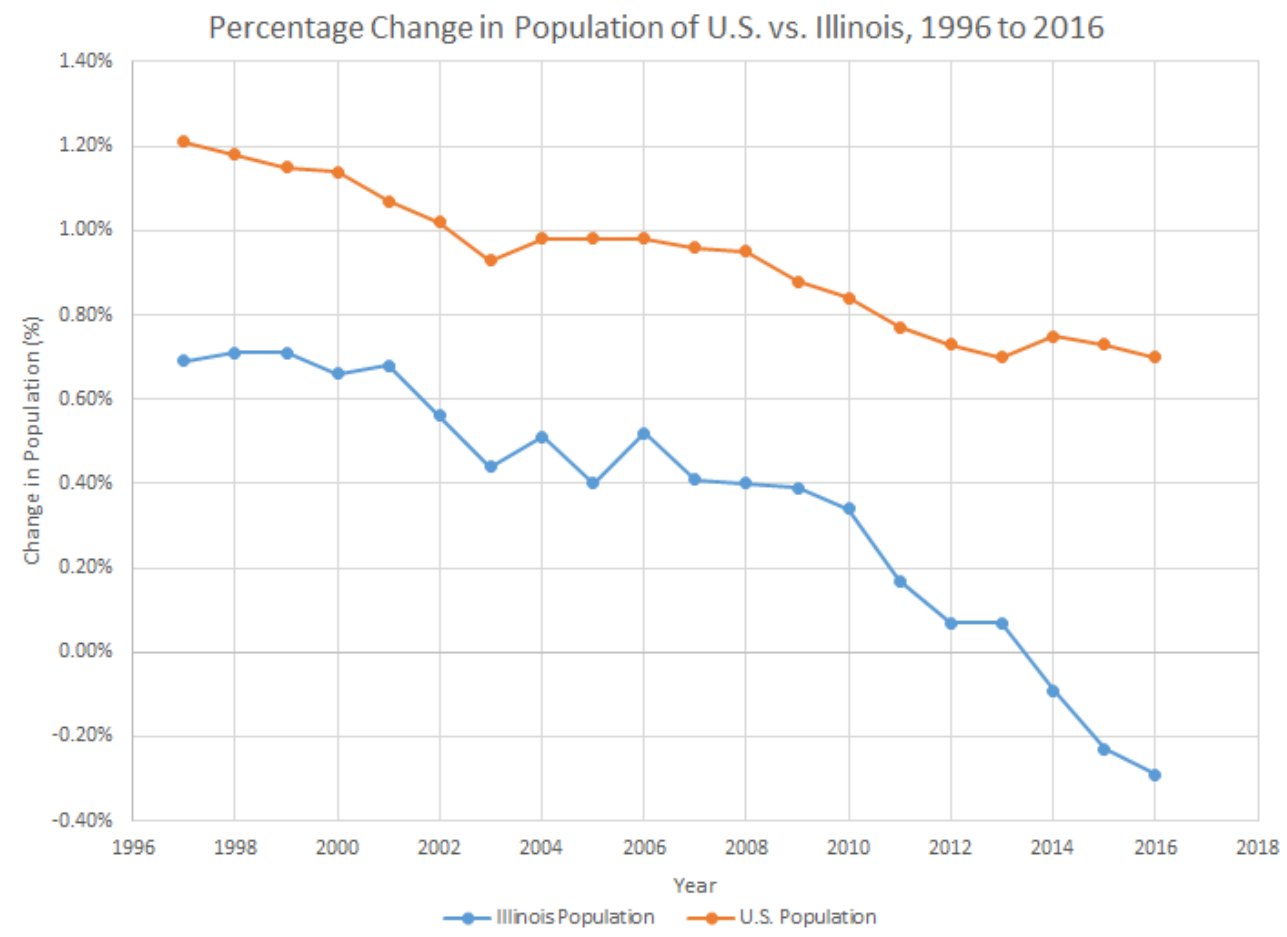

Figure 4. Percentage Change in Population of U.S. vs. Illinois, 1996 to 2016. Data gathered from Comprehensive Annual Financial Report for Fiscal Year Ended June 30, 2017, State of Illinois Comptroller (2017). 